\title{
The immunocompromised patient and transfusion
}

\author{
K G Badami
}

Immunocompromised patients are usually seriously ill and many such patients, especially those undergoing stem cell transplantation, have prolonged periods of pancytopenia and consequently, heavy transfusion requirements. ${ }^{1}$ All transfusions are potentially hazardous but transfusions to immunocompromised patients cause additional problems, which may be immunological or infectious. This review describes these special problems and ways to alleviate them. It should be useful to anyone treating immunocompromised patients particularly specialists in haematology, transfusion medicine, infectious diseases, oncology, transplant surgery, anaesthesia, and neonatology.

Different parts of the immune systemeither non-specific (phagocytes, complement, etc) or specific immunity (cellular or humoral) or combinations thereof may be affected. Patients with pure B cell immunodeficiency have few transfusion related problems. Both hereditary and acquired defects of the immune system occur (table 1). ${ }^{2}$ Inherited defects requiring transfusions are rare while acquired causes are relatively common. Neonates weighing less than $1200 \mathrm{~g}$ are physiologically immunocompromised. ${ }^{3}$

\section{Immunological hazards}

Problems such as haemolytic transfusion reactions and HLA alloimmunisation leading to transfusion refractoriness are well known and common to all patients. Less well known (but of particular importance to immunocompromised patients) is transfusion associated graftversus-host disease (TA-GvHD), mediated by donor derived, "passenger" $\mathrm{T}$ lymphocytes in cellular components, and immunomodulation that may increase the risk of infection and cancer recurrence.

TRANSFUSION ASSOCIATED GRAFT-VERSUS-HOST DISEASE

This has the same prerequisites as the GvHD that follows allogeneic stem cell transplanta-

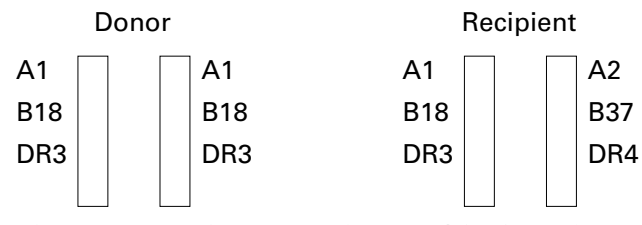

Figure 1 Donor homozygous for a HLA haplotype for which recipient is heterozygous.

tion, that is (a) immunocompetent donor $\mathrm{T}$ cells, (b) histoincompatibility between donor and recipient, and (c) inability of the recipient to reject donor $\mathrm{T}$ cells. It has been reported after stem cell (allogeneic as well as autologous) transplantation, after chemotherapy for acute leukaemia, in Hodgkin's disease, severe combined immune deficiency, and after neonatal and intrauterine transfusions. ${ }^{3-7}$ Neonates develop TA-GvHD especially if intrauterine transfusion is followed by postnatal exchange transfusion. It is believed that the intrauterine transfusion induces tolerance preventing the rejection of lymphocytes transfused subsequently. ${ }^{38}$ In aplastic anaemia, where there is usually no cellular immune deficiency, and in AIDS, where there is, no cases of TA-GvHD have been described..$^{90}$ In the case of AIDS, it may be that donor $\mathrm{T}$ cells are themselves infected by HIV, preventing their engraftment.

Rarely, immunocompetent patients can also suffer from TA-GvHD. This may happen when donor and recipient share HLA antigensparticularly if the donor is homozygous for an HLA haplotype that the recipient is heterozygous for. Under these circumstances, the recipient has HLA antigens that are foreign to the donor but not vice versa (fig 1).

The recipient therefore does not reject donor $\mathrm{T}$ lymphocytes that can recognise recipient HLA antigens as foreign and cause TA-GvHD. Three sorts of immunocompetent patients are prone to TA-GvHD: (a) patients receiving cellular components from close relatives, (b) patients in places such as Japan, where people often share a few common HLA haplotypes,

Table 1 Immunodeficiency states

\begin{tabular}{|c|c|c|}
\hline Primary involvement & Inherited & Acquired \\
\hline B cell & $\begin{array}{l}\text { - X linked hypogammaglobulinaemia } \\
\text { - Common variable immunodeficiency } \\
\text { - Selective isotype deficiency } \\
\text { - IgG subclass deficiency }\end{array}$ & - Splenectomy \\
\hline $\mathrm{T}$ cell & $\begin{array}{l}\text { DiGeorge syndrome } \\
\text { Defective T cell receptor expression, signal } \\
\text { transdusction or cytokine production }\end{array}$ & $\begin{array}{l}\text { - AIDS } \\
\text { - Cyclosporin, azathioprin } \\
\text { - Anti-T cell antibodies }\end{array}$ \\
\hline Combined $\mathrm{B}$ and $\mathrm{T}$ cell & $\begin{array}{l}\text { - Severe combined immunodeficiency (ADA, PnP, } \\
\text { MHC, IL-2r deficiency) } \\
\text { - Wiskott-Aldrich syndrome } \\
\text { - Ataxia telangiectasia } \\
\text { - Reticular dysgenesis }\end{array}$ & $\begin{array}{l}\text { - Haematological and non-haematological } \\
\text { malignancies } \\
\text { - Cytotoxic chemotherapy radiotherapy } \\
\text { - Stem cell transplantation } \\
\text { - Corticosteroids } \\
\text { - Protein calorie malnutrition }\end{array}$ \\
\hline Phagocytes & $\begin{array}{l}\text { - Chronic granulomatous disease } \\
\text { - Chediak-Higashi syndrome } \\
\text { - Job's syndrome }\end{array}$ & $\begin{array}{l}\text { - Acquired neutropenias } \\
\text { - Splenectomy }\end{array}$ \\
\hline Complement & - $\mathrm{C} 1-\mathrm{C} 9$ gene mutations & - Immune complex or autoimmune diseases \\
\hline
\end{tabular}

$\mathrm{ADA}=$ adenosine deaminase IL - interleukin; $\mathrm{MHC}=$ major histocompatibility complex; $\mathrm{PnP}=$ purine nucleoside phosphorylase. 
and (c) patients receiving HLA matched components. ${ }^{11-14}$

Cellular components like red blood cells (RBC), platelet and granulocyte concentrates and also fresh liquid plasma, but not previously frozen components like fresh frozen plasma, can cause TA-GvHD. ${ }^{15}$ Fresh blood $(<72$ hours) is a significant risk factor because lymphocyte viability declines during storage. ${ }^{16}$ Thus, in addition to the immune status of the host and the degree of HLA similarity between blood donor and recipient, TA-GvHD depends on the number and viability of lymphocytes transfused. The minimum dose of lymphocytes required for TA-GvHD was estimated to be $1 \times$ $10^{7} / \mathrm{kg}$ but TA-GvHD has been described even with filtered blood components which result in doses of $2-5 \times 10^{4}$ lymphocytes $/ \mathrm{kg}$. Hence, the quality and minimum dose of lymphocytes for TA-GvHD to develop remains uncertain. ${ }^{16}$ TA-GvHD presents four to 30 days after transfusion and can develop after even a single unit.

For reasons that are unclear, TA-GvHD is more severe than that occurring after allogeneic stem cell transplantation. Skin (erythematous maculopapular rash, which may progress to generalised erythroderma and bullae), gastrointestinal tract (diarrhoea) and liver (raised liver enzymes and bilirubin) are involved. In addition, fever, lymphadenopathy, and suppression of host haematopoiesis by donor $\mathrm{T}$ cells (reducing immunity further and causing thrombocytopenia and anaemia) commonly occur. ${ }^{17}$ Thus, TA-GvHD is easily confused for problems such as infection or treatment related toxicity in immunocompromised, ill patients and the diagnosis may be missed. Histological features of lesional tissues are characteristic and similar to those seen in classical GvHD. Conclusive diagnosis requires demonstration of HLA or sex chromosome chimerism. Treatment methods are similar to that for GvHD in other situations: high dose corticosteroids (for example, methyl prednisolone $1 \mathrm{~g} / \mathrm{m}^{2}$ followed by rapid taper), cyclosporin (for example, $6 \mathrm{mg} / \mathrm{kg}$ intravenously 12 hourly on alternate days) and sometimes, antilymphocyte globulin or anti-T cell antibodies. Supportive treatment (platelet and RBC transfusions, granulocyte colony stimulating factor, antibiotics, etc) may also be required. Mortality is nearly $90 \%$ despite treatment. ${ }^{4}$ Since treatment is so ineffective, it is important to prevent TA-GvHD from occurring.

TA-GvHD can be prevented in susceptible patients by avoiding unnecessary transfusion, careful donor selection and by inactivating lymphocytes with $\gamma$-irradiation or ultraviolet-B (UV-B) light. Current leucocyte filters, though capable of reducing total leucocyte numbers by $>3 \log _{10}(>99.9 \%)$, fail to prevent TA-GvHD because lymphocytes are not sufficiently reduced. Being affinity filters, cellular characteristics other than size, such as surface tension, adhesion and activation, also determine what cells are retained. ${ }^{18} \gamma$-Irradiation of cellular blood components to minimum doses of 2500 cGy (25 Gy) to the mid-plane of the container and $1500 \mathrm{cGy}$ to all other parts is used to prevent TA-GvHD. ${ }^{19}$ This prevents ${ }^{14} \mathrm{C}$-thymidine incorporation by lymphocytes after mitogenic stimuli. A 500-cGy dose may suffice to prevent the physiologically relevant proliferation in mixed lymphocyte culture. ${ }^{20}$ Doses $<5000$ cGy do not affect RBC, platelet, or granulocyte function and survival adversely. ${ }^{21}$ Dedicated blood irradiators (containing a shielded ${ }^{137} \mathrm{cae}-$ sium source) or conventional facilities may be used. $^{22}$ Irradiation of an RBC unit or of six units of platelets takes around two minutes. The delivered dose is a function of the residual radioactivity of the source and time of exposure. With time, exposure needs to be increased to achieve the required dose. Irradiated cellular components (other than stem cell grafts and donor lymphocyte infusions given for a graft-versus-tumour effect) are used for the following categories of patients (box 1).

An alternative to $\gamma$-irradiation is exposure to UV-B light (280-320 nm), which abolishes the capacity of lymphocytes to respond as well as to stimulate. This is potentially simple and inexpensive but the equipment is not readily available and it is difficult to ensure uniform UV exposure. Furthermore, standard blood bag plastic is opaque to UV light, requiring the use of special bags. ${ }^{24}$ UV-B for the prevention of TA-GvHD is still experimental.

\section{IMMUNOMODULATION}

This poorly understood phenomenon is believed to be caused by transfused leucocytes leading to a decrease of $\mathrm{T}$ and $\mathrm{B}$ lymphocytes, natural killer cells, and monocytes. ${ }^{25}$ Immunomodulation is reported to increase haematological and non-haematological tumour recurrence (though this is challenged; see below), and infection after surgery. ${ }^{24-26} 27$ Pre-storage leucodepletion (see below) may reduce this problem, but there is no consensus on this issue. $^{2829}$

\section{Infectious hazards}

All blood donations are screened for infections such as hepatitis B and HIV that are dangerous to all transfusion recipients-immunocompetent or otherwise. But agents such as cytomegalovirus (CMV) that cause few problems in immunocompetent individuals can cause serious disease in immunocompromised patients.

\footnotetext{
Box 1: Patients who should receive irradiated cellular components

Established indications

- Postallogeneic stem cell transplant when absolute lymphocyte count is $<0.5 \times 10^{9} / 1 .{ }^{19}$

- Some immunodeficient patients. ${ }^{19}$

- Intrauterine transfusions. ${ }^{19}$

- Transfusions from close relatives. ${ }^{19}$

Doubtful indications

- Patients with chronic GvHD. ${ }^{23}$

- Postautologous stem cell transplantation. ${ }^{23}$

- Patients with malignancies when absolute lymphocyte count $<0.5 \times 10^{9} / 1$. $^{19}$

- Patients with AIDS. ${ }^{10}$

- Neonates $<1200$ g. $^{23}$

- Recipients of HLA matched cellular blood components. ${ }^{23}$
} 
CYTOMEGALOVIRUS INFECTION

This widespread herpes virus is often acquired perinatally or in childhood. Seropositivity rates in apparently healthy adults are $30 \%$ to $80 \%$ in developed countries and nearly $100 \%$ in developing countries. ${ }^{30}$ In immunocompetent subjects a mild or subclinical infection is caused, which may persist in latent form in leucocytes. Because of the high prevalence, blood donations are not routinely tested for CMV. In immunocompromised patients, CMV can cause a severe, disseminated infection resulting in interstitial pneumonitis, hepatitis, retinitis, enteritis, and encephalitis. ${ }^{31} \mathrm{CMV}$ causes tissue injury directly as well as by non-cytopathic means, where CD8+ cytotoxic T lymphocytes lyse cells displaying viral antigens in conjunction with HLA class I molecules. ${ }^{32}$ The risk of acquiring infection is proportional to the number of donor exposures.

CMV transmission can be prevented either by using blood from CMV negative donors or by leucodepleting cellular components. ${ }^{33} 3435$ Screening tests for CMV involve the detection of specific $\operatorname{IgM}$ or IgG antibody by enzyme linked immumosorbent assay. IgM indicates an acute infection and IgG, past exposure. CMV positive individuals have either anti-CMV IgG or IgM and negative individuals neither. Only $3 \%-12 \%$ of CMV positive donors may be able to transmit CMV. ${ }^{35}$ It was suggested that antiCMV IgM positive (+/-IgG) donations are more infectious than IgG positive, IgM negative ones but this remains unproved. ${ }^{10}$ Other methods of CMV diagnosis are viral culture, antigen detection, shell vial assay, and polymerase chain reaction. These are useful in patients but not blood donors. In CMV positive, immunocompromised patients, reactivation of latent, endogenous infection is more common than transfusion derived infection. Hence, such patients and CMV negative recipients of CMV positive stem cell or organ grafts are not usually given CMV negative components. ${ }^{36}$

Third generation leucocyte filters remove neutrophils and monocytes efficiently without excessive RBC or platelet loss. Filtered components are equivalent to CMV negative donations if residual leucocytes are $<5 \times 10^{6}$ per RBC unit or adult therapeutic dose of platelets. ${ }^{30}$ Leucodepletion for selected patients means that an inventory of CMV negative donors is unnecessary - a particular advantage in many developing countries where the availability of seronegative donors (and the demand for seronegative blood) is small. But, before advocating expensive filters for this purpose, studies on the natural history of CMV infection in immunocompromised patients in these countries are needed. The advantages of leucodepletion are listed in box 2 .

The levels of leucodepletion required for preventing HLA alloimmunisation and FNHTR are $5 \times 10^{6}$ and $5 \times 10^{8}$ respectively. ${ }^{19}$ Potential multitransfusion patients (such as transplant patients and those undergoing treatment for malignancies) should receive leucodepleted components. Separate filters are used for RBC and platelets. Pre-storage filtration is better than post-storage (laboratory) or pre-
Box 2: Advantages of leucodepletion

- CMV transmission.

- HLA alloimmunisation in multiply transfused patients. ${ }^{37} 38$

- Some febrile non-haemolytic transfusion reactions. ${ }^{37} 39$

- ?Human T cell leukaemia virus transmission. ${ }^{40}$

- ?Epstein-Barr virus transmission. ${ }^{40}$

- ?Bacterial infection. ${ }^{3741}$

- ?Tumour recurrence. ${ }^{28}{ }^{37}$

- ?TA-GvHD. ${ }^{15}$

- ?Some transfusion associated lung injury. ${ }^{37} 42$

transfusion (bedside) filtration for at least three reasons. Firstly, it is less cumbersome, better controlled, and has fewer failures. ${ }^{43}$ Secondly, cytokine release by leucocytes is prevented and this may reduce febrile non-haemolytic transfusion reaction. ${ }^{44}$ Thirdly, leucocytes are removed before they can disintegrate and release free virus such as CMV into the plasma. ${ }^{46}$ Disadvantages of leucodepletion include cost, time, increased leukaemia relapse due to the loss of the graft-versus-leukaemia effect (though this is challenged; see above) and occasional hypotensive reactions, possibly due to plasma-protein activation and bradykinin release. ${ }^{47} 48$

The following categories of patients (box 3), but not patients undergoing non-myeloablative chemotherapy, may need CMV negative or leucodepleted cellular components. ${ }^{49}$ Obviously, stem cell transplants, donor lymphocyte infusions, and granulocyte concentrates must never be leucofiltered!

Leucodepletion by other means such as centrifugation, washing, freezing, and thawing may be insufficient to prevent CMV transmission. $\gamma$-Irradiation cannot be used because the dose needed to inactivate the virus can damage blood cells. ${ }^{50}$ Other methods are used to prevent overt CMV infection (exogenous or reactivation) in allogeneic stem cell transplant

Box 3: Patients who may need CMV negative or leucodepleted cellular components

Established indications

- CMV negative recipients of CMV negative stem cell allografts.

- CMV negative recipients of CMV negative organ allografts.

- CMV negative AIDS patients.

- CMV negative patients with inherited immunodeficiencies.

- CMV negative pregnant women.

- Fetuses needing intrauterine transfusion.

- Neonates $<1200 \mathrm{~g}$ with a CMV negative mother.

Doubtful indications

- CMV negative stem cell autograft recipients.

- CMV negative patients undergoing splenectomy. 


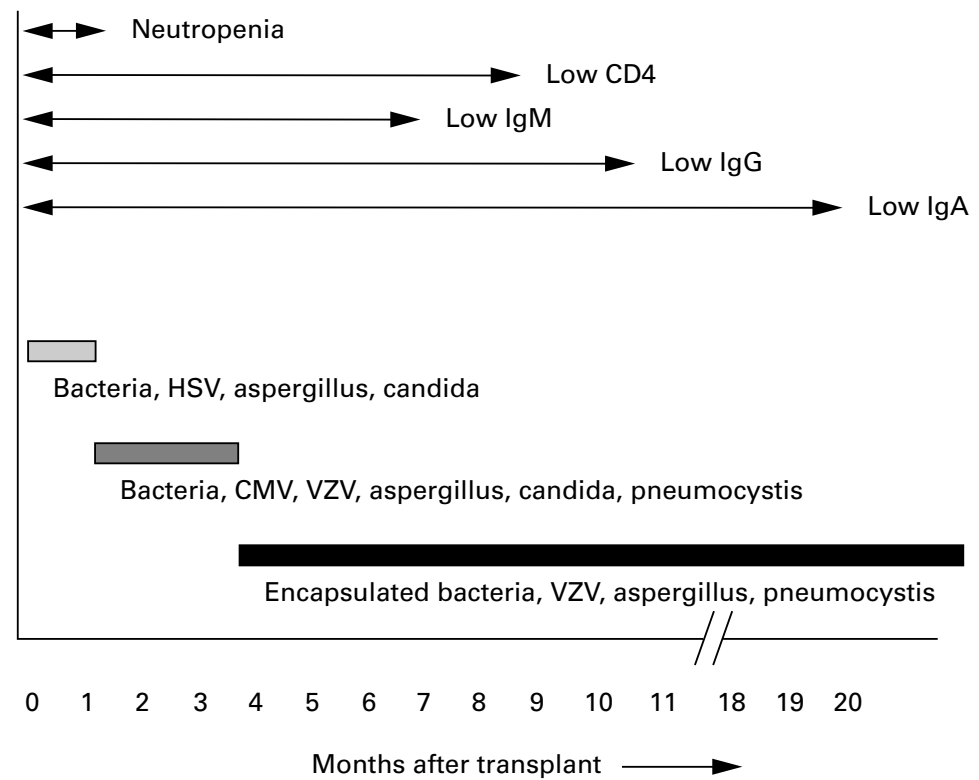

Figure 2 Immune deficiency and infection hazards after allogeneic stem cell transplantation $(C M V=$ cytomegalovirus; $H S V=$ herpes simplex virus; $V Z V=$ varicella zoster virus).

patients. ${ }^{51}$ These include, (a) weekly surveillance cultures from day 30 to 100 posttransplant, (b) pre-emptive gancyclovir, if surveillance cultures are positive, and (c) acyclovir and intravenous IgG from day 7 to 100 post-transplant. CMV infections in immunocompromised patients are usually treated with gancyclovir and CMV immune globulin but mortality is high, especially with CMV interstitial pneumonitis.

\section{OTHER INFECTIONS}

Immunocompromised patients are also prone to other infections - viral, bacterial, fungal, and protozoal. For instance, allogeneic stem cell transplant patients often have a characteristic sequence of infections (fig 2) but such infections are often either endogenous or have portals of entry other than transfusion..$^{51}$ Obviously, infected units can cause serious disease, particularly in neutropenic and splenectomised patients. Non-leucoreduced, allogeneic cellular components, by causing "immunomodulation" (see above), may exacerbate infection.

Other common herpes viruses including Epstein-Barr virus (EBV) and the human herpes viruses (HHV) 6, 7, and 8 are also important in this setting. EBV like CMV causes a mild, self limited infection in immunocompetent subjects. EBV is latent in B lymphocytes and can be transmitted through cellular blood components but this is uncommon because of the presence of neutralising anti-EBV antibodies in the donation itself. Only if the units transfused are exclusively from a donor who does not have such antibodies, can posttransfusion EBV infection occur-and then, only rarely in immunocompetent patients in whom EBV specific, cytotoxic $\mathrm{T}$ lymphocytes prevent uncontrolled B lymphocyte proliferation. In immunocompromised patients, posttransfusion EBV infection can lead to EBV associated lymphomas. ${ }^{52}$
Box 4: Summary and learning points

- Immunocompromised patients receive more transfusions.

- Tranfused leucocytes cause special problems.

- TA-GvHD is caused by donor T cells.

- Irradiating cellular components prevents TA-GvHD.

- Leucocytes cause immunomodulation increasing infection and tumour recurrence.

- Leucodepletion reduces problems due to immunomodulation.

- CMV latent in leucocytes can cause disseminated infection.

- CMV negative blood or effective leucodepletion prevent CMV transmission.

- EBV may cause B cell lymphoma and parvovirus B19 can affect haemopoiesis.

- Pre-storage is better than post-storage leucodepletion.

HHV 6-8 are also lymphotropic and have biological and epidemiological similarities to CMV including latency. ${ }^{53}$ Hence, transmission through transfusion is possible. The rare reports of serious infections with these viruses in immunocompromised patients suggest that they were reactivations of latent infection. It is uncertain if HHV seronegative, immunocompromised recipients need HHV negative transfusions. ${ }^{54}$

Some immunocompromised patients may have pure red cell aplasia due to persistent infection with parvovirus B19, which is transfusion transmissible, particularly through coagulation factor concentrates. ${ }^{55}$ This has been reported in patients with AIDS, Nezelof's syndrome, and in children in remission after treatment for acute lymphoblastic leukaemia. ${ }^{56-58}$ Thrombocytopenia may also occur. ${ }^{59}$ Infection is treatable with immunoglobulin infusions. The parvovirus B19 seropositivity rate among blood donors is $30 \%-60 \%$ but many probably merely represent past exposure. Donors capable of transmitting the infection are estimated to be only about $0.03 \%$ and it is not clear if, when, and how donations need to be screened. ${ }^{60}$

1 Smith OP, Prentice HG, Hazelhurst G, et al. Blood product support for patients undergoing chemotherapy and bone marrow transplantation for haematological malignancies. $\mathrm{Br}$ marrow transplantation for haem

2 Abbas AK, Lichtman AH, Pober JS. Cellular and molecular Amman AK, Lichtman AH, Pober JS. Cellular and
immologhiladelphia: WB Saunders, 1994.

3 Sanders MR, Graeber JE. Posttransfusion graft-versus-host disease in infancy. F Pediatr 1990;117:159-63.

4 von Fliedner V, Higby DJ, Kim U. Graft-versus-host reaction following blood product transfusion. Am $\mathcal{F}$ Med 1982;72 951-61.

5 Ford JM, Lucey JJ, Cullen MH, et al. Fatal graft-versus-host disease following transfusion of granulocytes from normal donors. Lancet 1976;ii:1167.

6 Burns LJ, Westberg MW, Burns CF, et al. Acute graft-versus host disease resulting from normal blood transfusion. Acta Haematol 1984;71:270-6.

7 Strobel S, Morgan G, Simmonds AH, et al. Fatal graft versus host disease after platelet transfusions in a child with purine nucleoside phosphorylase deficiency. Eur $\mathcal{F}$ Pediatr purine nucleoside

8 Linden JV, Pisciotto PT. Transfusion-associated graftLinden JV, Pisciotto PT. Transfusion-associated graft-
versus-host disease and blood irradiation. Transfusion Medicine Reviews 1992;6:116-23. 
9 Young NS. Acquired bone marrow failure In: Handin RI, Stossel TP, Lux SE, eds. Blood: principles and practice of hematology. Philadelphia: JB Lippincott, 1995: 293-376.

10 McCullough J. Transfusion medicine. In: Handin RI, Stossel TP, Lux SE, eds. Blood: principles and practice of hematology. Philadelphia: JB Lippincott, 1995: 1947-2006.

11 Petz LD, Calhoun L, Yam P, et al. Transfusion-associated graft-versus-host disease in immunocompetent patients: report of a fatal case associated with transfusion from a second degree relative and a survey of predisposing factors. Transfusion 1993;33:742-50.

12 Thaler M, Shamis A, Orgad S, et al. The role of blood from HLA-homozygous donors in fatal transfusion-associated graft-versus-host disease after open-heart surgery. $N$ Engl f Med 1989;321:25-8

13 Juji T, Shibata Y, Ide $\mathrm{H}$, et al. Post transfusion-associated graft-versus-host disease in immunocompetent patients after cardiac surgery in Japan. N Engl F Med 1989;321:56.

14 Dinsmore RE, Straus DJ, Pollack MS, et al. Fatal graft-versus-host disease following blood transfusion in
Hodgkin's disease documented by HLA typing. Blood 1980; 55:831-4

15 Anderson KC, Weinstein HJ. Transfusion associated graft-versus-host disease. N Engl f Med 1990;323:315-19.

16 Ohto H, Anderson KC. Posttransfusion graft-versus-host disease in Japanese newborns. Transfusion 1996;36:117-23.

7 Brubaker DB. Human posttransfusion graft-versus-host disease. Vox Sang 1983;45:401-20.

18 Bruil A, Beugeling T, Feijen J, et al. The mechanisms of leukocyte removal by filtration. Transfusion Medicine Reviews 1995;9:145-66.

19 Klein HG, ed. Standards for blood banks and transfusion services. Bethesda, MD: American Association of Blood Banks, 1996.

20 Sprent J, Anderson RE, Miller JFAP. Radiosensitivity of T and $\mathrm{B}$ lymphocytes. II. Effect of irradiation on response of $\mathrm{T}$ cells to alloantigens. Eur F Immunol 1974;4:204-10.

21 Button LN, DeWolf WC, Newburger PE, et al. The effects of irradiation on blood components. Transfusion 1981;21 419-26.

22 Patterson K. Blood and blood product transfusion during bone marrow transplantation. In: Treleaven J, Barrett B, eds. Bone marrow transplantation in practice. Edinburgh: Churchill Livingstone, 1992: 307-14.

23 Vengelen-Tyler V, ed. Technical manual. 12th Ed. Bethesda: American Association of Blood Banks, 1996.

24 Capon SM, Sacher RA, Deeg HJ. Effective ultraviolet irradiation of platelet concentrates in Teflon bags. Transfusion 1990;30:678-81.

25 Triulzi DJ, Vanek K, Ryan DH, et al. A clinical and immunologic study of blood transfusion and postoperative bacterial infection in spinal surgery. Transfusion 1992:32:517-24.

26 Oksanen K, Elonen E. Impact of leucocyte-depleted blood components on the haematological recovery and prognosis of patients with acute myeloid leukaemia. $\mathrm{Br} \mathcal{F}$ Haematol 1993;84:639-47.

27 Chung M, Steinmetz OK, Gordon PH. Perioperative blood transfusion and outcome after resection for colorectal carcinoma. Br F Surg 1993;80:427-32.

28 Bordin JO, Bardossy L, Blajchmann MA. Growth enhancement of established tumors by allogeneic blood transfusion in experimental animals and its amelioration by leukodepletion: the importance of the timing of the leukodepletion. Blood 1994;84:344-8.

29 Vamvakas EC. Transfusion-associated cancer recurrence and postoperative infection: meta analysis of randomized controlled clinical trials. Transfusion 1996;36:175-86.

30 Preiksaitis J. Indications for the use of cytomegalovirusseronegative blood products. Transfusion Medicine Reviews 1991;5:1-17.

31 Finch RG, Ball P. Infection. Oxford: Blackwell Scientific Publications, 1991

32 Grundy JE, Shanley JD, Griffiths PD. Is cytomegalovirus interstitial pneumonitis in transplant recipients an immunopathological condition? Lancet 1987;ii: $996-9$.

33 Miller WJ, McCullough J, Balfour $\mathrm{HH}$ Jr, et al. Prevention of cytomegalovirus following bone marrow transplantation: a cytomegalovirus following bone marrow transplantation: a
randomized clinical trial of blood product screening. Bone Marrow Transplant 1991;7:227-34.

34 Hillyer CD, Emmens RK, Zago-Novaretti M, et al. Methods for the reduction of transfusion-transmitted cytomegalovirus infection: filtration versus the use of seronegative dono units. Transfusion 1994;34:929-34.

35 Adler SP. International forum; transfusion transmitted CMV infections. Vox Sang 1984;46:387-414.
36 Hillyer CD, Snydman DR, Berkman EM. The risk of cytomegalovirus infection in solid organ and bone marrow transplant recipients: transfusion of blood products. Blood 1990;30:659-66.

37 Bordin JO, Heddle NM, Blajchmann MA. Biologic effects of leukocytes present in transfused cellular blood products. Blood 1994;84:1703-2

38 Saarinen UM, Koskimies S, Myllyla G. Systematic use of leukocyte-free blood components to prevent alloimmunization and platelet refractoriness in multitransfused patients with cancer. Vox Sang 1993;65:286-92.

39 Dzieczkowski JS, Barrett BB, Nester D, et al. Characterization of reactions after exclusive transfusion of white cell-reduced cellular blood components. Transfusion 1995; 35:20-5.

40 Goldman M, Delage G. Role of leukodepletion in the control of transfusion-transmitted disease. Transfus Med Rev 1995;1:9-19.

41 Sazama K. Bacteria in blood for transfusion: a review. Arch Pathol Lab Med 1994;118:350-65.

42 Van Buren NL, Stroncek DF, Clay ME, et al. Transfusion related acute lung injury caused by an NB2 granulocytespecific antibody in a patient with thrombotic thrombocytopenic purpura. Transfusion 1990:30:42-5.

43 Popovsky MA. Quality of blood components filtered before storage and at the bedside: implications for transfusion practice. Transfusion 1996;36:470-4.

44 Heddle NM, Klama L, Singer J, et al. The role of plasma from platelet concentrates in transfusion reactions. N Engl f Med 1994;331:625-8.

45 Shanwell A, Kristiansson M, Remberger M, et al. Generation of cytokines in red cell concentrates during storage is transfusion 1997;37:678-84.

46 James DJ, Sikotra S, Sivakumaran M, et al. The presence of free infectious cytomegalovirus (CMV) in the plasma of donated CMV-seropositive blood and platelets. Transfusion Medicine 1997;7:123-6.

Medicine 1997;7:123-6.
47 Tucker J, Murphy MF, Gregory WM, et al. Apparent removal of graft-versus-leukaemia effect by the use of leukocyte-poor blood components in patients with acute myeloblastic leukaemia. Br f Haematol 1989;73:584-5.

48 Fried MR, Eastlund T, Christie B, et al. Hypotensive reactions to white cell-reduced plasma in a patient undergoing angiotensin-converting enzyme inhibitor therapy. Transfusion 1996;36:900-3.

49 Sayers MH, Anderson KC, Goodnough LT, et al. Reducing the risk for transfusion-transmitted cytomegalovirus infection. Ann Intern Med 1992;116:55-62.

50 Wagner SJ, Friedman LI, Dodd RY. Approaches to the reduction of viral infectivity in cellular blood components and single donor plasma. Transfus Med Rev 1991;5:18-32.

51 Burt RK, Walsh $\mathrm{T}$. Infection prophylaxis in marrow transplant recipients-myths, legends and microbes. In: , Deeg HJ, Lothian ST, et al, eds. Bone marrow transplantation. Austin: RG Landes, 1996: 438-50.

52 Hanto DW, Gajl-Peczalska KJ, Frizzera G, et al. EpsteinBarr virus (EBV)-induced polyclonal and monoclonal B-cell lymphoproliferative diseases occurring after renal transplantation. Ann Surg 1983;198:356-69.

53 Brooks GF, Butel JS, Morse SA. Fawetz, Melnick \& Adelberg's medical microbiology. Stamford: Appleton and Lange, 1998.

54 Sayers MH. Cytomegalovirus and other herpesviruses. In: Petz LD, Swisher SN, Kleinman S, et al, eds. Clinical practice of tranfusion medicine. New York: Churchill Livingstone, 1996: 875-89.

55 Williams MD, Cohen BJ, Beddall AC, et al. Transmission of human parvovirus B19 by coagulation factor concentrates. Vox Sang 1990;58:177-81.

56 Frickhofen N, Abkowitz JL, Safford M, et al. Persistent B19 parvovirus infection in patients infected with human immunodeficiency virus type 1 (HIV-1): a treatable cause of anaemia in AIDS. Ann Intern Med 1990;113:926-33.

57 Kurtzmann G, Ozawa K, Cohen B, et al. Chronic bone marrow failure due to persistent B19 parvovirus infection. $N$ Engl f Med 1987;317:287-94.

58 Kurtzmann G, Cohen B, Myers P, et al. Persistent B19 parvovirus infection as a cause of severe anaemia in children with acute lymphoblastic leukaemia in remission. Lancet 1988;ii: 1159 .

59 Nagai K, Morohoshi T, Kudoh T, et al. Transient erythroblastopenia of childhood with megakaryocytopenia associated with human parvovirus B19 infection. Br f Haematol 1992;80:131-2

60 Lublan NLC. Human parvoviruses: implications for transfusion medicine. Transfusion 1994;34:821-7. 